$$
\begin{aligned}
& \text { 최근 } 3 \text { 년간 기저질환이 없는 소아 입원 환자에서 호흡기 } \\
& \text { 바이러스에 따른 급성 하기도 감염의 임상적 특징 } \\
& \text { 서민해 }{ }^{1}, \text { 김형영 }{ }^{1}, \text { 엄태민 }{ }^{1}, \text { 김혜영 }^{2}, \text { 박희주 }^{1} \\
& { }^{1} \text { 부산대학교 의학전문대학원 소아청소년과학교실, }{ }^{2} \text { 부산대학교병원 소아청소년과 }
\end{aligned}
$$

\title{
Clinical characteristics of acute lower respiratory tract infections according to respiratory viruses in hospitalized children without underlying disease during the last 3 years
}

\author{
Min Hae Seo', Hyung Young $\mathrm{Kim}^{1}$, Tae Min Um ${ }^{1}$, Hye-Young Kim², Hee-Ju Park ${ }^{1}$ \\ ${ }^{I}$ Department of Pediatrics, Pusan National University School of Medicine, Yangsan; \\ ${ }^{2}$ Department of Pediatrics, Pusan National University Hospital, Busan, Korea
}

Background: Respiratory viruses play a significant role in the etiology of acute respiratory infections and exacerbation of chronic respiratory illnesses. This study was conducted to identify the epidemiological and clinical characteristics of children with acute viral lower respiratory infections.

Methods: This study investigated 1,168 children diagnosed with acute viral lower respiratory tract infections (RTIs) between January 2012 and December 2014. Specimens of respiratory viruses were collected using a nasopharyngeal swab and analyzed by reverse transcriptase polymerase chain reaction. We retrospectively reviewed the medical records and analyzed the clinical features of children hospitalized for acute lower respiratory infections.

Results: Respiratory syncytial virus (RSV), the main cause of infection in children aged $<5$ years, was the most commonly detected pathogen in children with bronchiolitis and pneumonia, and resulted in high proportions of children requiring oxygen treatment and intensive care unit admission. Rhinovirus was preceded by RSV as the second most common cause of bronchiolitis and pneumonia, and was detected most frequently in the children aged $\geq 6$ years. In addition, asthma was predominantly caused by rhinovirus in children aged $\geq 6$ years, whereas croup was mostly caused by parainfluenza virus in those aged $<5$ years. Rhinovirus infection $(p<0.001)$ and history of asthma $(p=0.049)$ were identified as significant risk factors for readmission within a month.

Conclusion: We identified the epidemiological and clinical characteristics of respiratory viruses in children with acute lower respiratory infections during the last 3 years. Our findings may provide useful clinical insight to comprehend the acute viral lower RTls in children.

Keywords: Respiratory tract infection; Viruses; Pneumonia; Bronchiolitis; Child

Received: December 29, 2016, Revised: June 5, 2017

Accepted: June 8, 2017

Corresponding Author: Hee-Ju Park, Department of Pediatrics, Pusan National University School of Medicine,

20 Geumo-ro, Meulgeum-eup, Yangsan 50612, Korea

Tel: +82-55-360-3150, Fax: +82-55-360-2181

E-mail: phj7294@hanmail.net

\section{서 론}

급성 하기도 감염은 소아에서 가장 흔한 질환 중의 하나로 대부분의 원인은 respiratory syncytial virus (RSV), human rhinovirus (HRV), parainfluenza virus (PIV), influenza A virus (Influ A), influenza B virus (Influ B), human metapneumovirus (hMPV),

Copyright (C) 2017 Yeungnam University College of Medicine

This is an Open Access article distributed under the terms of the Creative Commons Attribution Non-Commercial License (http://creativecommons.org/licenses/by-n/4.0/) which permits unrestricted non-commercial use, distribution, and reproduction in any medium, provided the original work is properly cited. 
human adenovirus (HAdV), human coronavirus (HCoV), human bocavirus ( $\mathrm{HBoV}$ )와 같은 바이러스이다[1-3]. 그 외 폐렴 사슬알균(Streptococcus pneumoniae), 인플루엔자균(Haemophilus influenzae), 황색포도알균(Staphylococcus aureus), 폐렴 미코플라스마(Mycoplasma pneumoniae)와 같은 세균뿐 아 니라, 곰팡이도 급성 하기도 감염의 원인이 된다[4,5].

이전 국내 연구에 따르면 급성 하기도 감염으로 입원한 소 아 환자의 원인 가운데 바이러스는 9.8-35.8\%를 차지하였고, 특히 2세 미만의 영유아에서 높은 유병률을 보였으며, 폐렴 이 72.2-73.0\%로 가장 흔한 진단이었고, 다음으로 세기관지 염이 14.5-20.9\%를 차지하였다[6,7]. 폐렴과 세기관지염은 $\mathrm{RSV}$ 가 가장 흔한 원인이었고, 크룹(croup)은 PIV와 HRV가 주요 원인이었으며, 천식의 원인은 대부분 $\mathrm{HRV}$ 나 RSV였고 기관기관지염은 $\mathrm{HAdV}, \mathrm{HRV}$ 및 RSV 등 다양한 바이러스가 원인으로 확인되었다[8,9]. 본 연구자들의 이전 연구에서 2010년 5월부터 2011년 4월까지 바이러스로 인한 급성 하 기도 감염으로 입원한 환자 1,102 명 가운데 폐렴이 $52.3 \%$ 로 가장 흔한 진단이었다. 다음으로 흔한 진단은 세기관지염 (21.2\%)이었으며, RSV는 폐렴과 세기관지염의 주요 원인으 로, PIV는 크룹의 주요 원인으로, 그리고 hMPV는 폐렴의 주요 원인임을 보고한 바 있다[10].

대부분의 이전 연구들은 바이러스로 인한 급성 하기도 감염 환자들을 대상으로 역학적 및 임상적 특징을 기술하였으나 기저질환 여부에 따른 구분이 명확하지 않았다. 특히 만성적인 기저질환이 있을 경우 기저질환이 없는 소아에 비하여 호흡 기 바이러스에 의한 급성 하기도 감염의 치료 경과나 예후에 영향을 미칠 수 있기 때문에 호흡기 바이러스로 인한 급성 하기도 감염의 임상적 특징을 해석하는데 주의가 필요하다. 이번 연구에서는 최근 3년간 만성적인 기저질환이 없는 입원 환자를 대상으로 바이러스성 급성 하기도 감염의 임상적 및 역학적 특징을 알아보고, 한 달 이내 재입원의 위험요인을 알아보고자 하였다.

\section{재료 및 방법}

\section{1. 대상}

이번 연구는 2012년 1월부터 2014년 12월까지 부산대학교 어린이병원과 부산대학교병원 소아청소년과에서 급성 하기도 감염으로 입원한 환자 1,743 명 가운데, 임신나이 35 주 미만 의 미숙아, 기관지폐형성이상 및 폐쇄세기관지염 등 만성호
흡기질환, 선천성심장기형을 포함한 선천성질환, 신경질환, 신장질환, 혈액종양질환, 유전대사질환, 면역결핍질환 등의 병력이 있는 122 명 및 호흡기 바이러스가 검출되지 않은 221명 을 연구 대상에서 제외하였다. 또한 개별적인 바이러스에 따른 임상적 특징을 알아보기 위해 두 가지 이상 바이러스가 중복 검출된 232명을 제외하여 최종적으로 한 가지 바이러 스만 검출된 1,168 명을 대상으로 하였다.

\section{2. 방법}

호흡기 바이러스 감염은 환자들의 코인두 흡인물을 채취 하여 AdvanSure RV real-time polymerase chain reaction (RTPCR) Kit (LG Life Sciences, Daejeon, Korea)로 확인하였으며 [10], 2012년 1월부터 2013년 7월까지는 7가지 종류(RSV, HRV, PIV, Influ A, Influ B, hMPV, HAdV)의 바이러스를 검사하였고, 2013년 8월부터 2014년 12월까지는 13가지 종류 (RSV, HRV, PIV [type 1, type 2, and type 3], Influ A, Influ B, hMPV, HAdV, HCoV [229E, OC43, and NL63], HBoV)의 바이러스를 검사하였다. 또한, 혈액 세균배양 검사, 비인두 분비물 및 객담의 세균배양 및 Mycoplasma pneumoniae PCR 검사, 흥수의 세균배양 및 Mycoplasma pneumoniae PCR 검사, 혈청학적 검사(Mycoplasma pneumoniae, Chlamydia pneumonmiae, Chlamydia trachomatis, Legionella pneumophila), 투베르쿨린 검사 등의 검사를 선별적으로 시행하여 다른 호 흡기 감염원이 확인된 환자들은 연구 대상에서 제외하였다.

급성 하기도 감염은 Denny와 Clyde의 정의 및 분류[11]에 따라 컹컹거리는 기침을 하고 쉰 목소리가 나며 흡기 시 협착 음이 있는 경우는 크룹으로, 젖은 기침(productive cough)을 하고 청진 시 주로 수포음이 들리며 가슴 X선검사에서 폐 침윤이 없을 경우는 기관기관지염으로 진단하였다. 또한, 청진 시 주로 호기성 천명음이 들리고 가슴 $\mathrm{X}$ 선검사가 정상 혹은 과팽창 소견을 보일 경우는 세기관지염으로, 청진 시 수포음 이 들리거나 가슴X선검사에서 폐 침윤이 있을 경우는 폐렴 으로 진단하였다. 천식의 진단은 5 세 이상에서 반복적인 기침, 천명음, 호흡곤란의 증상이 있으면서 다음과 같은 검사결과 이상이 있을 때로 정의하였다. 폐기능 검사에서 1 초 강제호기 량(forced expiratory volume in 1 second, $\mathrm{FEV}_{1}$ )이 $80 \%$ 이하 로 감소하거나 기관지 확장제를 투여한 후 $\mathrm{FEV}_{1}$ 이 $12 \%$ 이상 증가한 경우 또는 메타콜린 기관지유발시험에서 $\mathrm{FEV}_{1}$ 이 $20 \%$ 이상 감소했을 때의 메타콜린 농도가 $8 \mathrm{mg} / \mathrm{mL}$ 이하일 경우에 천식으로 진단하였다[12]. 폐기능검사를 할 수 없는 
소아에서는 3 회 이상 반복적인 천명이 있고, 천식의 고위험군 이면서 기관지 확장제를 흡입한 이후 증상이 호전되었을 경 우 천식으로 진단하였다[13].

\section{3. 통계}

정규분포를 만족하지 않은 나이와 입원 일수는 중위수와 사분위수범위로 기술하였다. 명목변수는 대상자 수와 백분 율로 기술하였고, 나이에 따른 바이러스 차이, 진단명에 따른 바이러스 차이, 나이에 따른 진단명의 차이는 카이제곱 또는 Fisher's exact test로 분석하였다. 바이러스 분포와 진단명의 나이에 따른 경향성은 Mantel-Haenszel chi-square test for trend로 분석하였다. 한 달 이내 재입원에 미치는 요인에 대 한 분석은 나이, 성별, 입원하였던 병원을 보정하여 다변량 로지스틱회귀분석을 사용하여 adjusted odds ratio (aOR)와 $95 \%$ confidence interval (CI)을 구하였다. 모든 통계 분석은 R program (version 3.2.3)을 이용하였고, $p$ 값이 0.05 미만인 경 우 통계적으로 유의한 것으로 판단하였다.

\section{결 과}

\section{1. 연구 대상자의 특징}

한 가지 바이러스만 검출된 1,168 명의 연구 대상자의 중간 나이(median age)는 1세였으며, 남자 717명과 여자 451명이 었다. 연도별로 2012년도 476명, 2013년도 339명, 2014년 도 353 명이었다. 계절적인 분포는 여름에 환자 수가 적었고, 그 외 계절은 비슷하였다. 진단은 폐렴 493명, 세기관지염 372 명, 크룹 204명 순서로 많았으며, 산소치료 123명, 중환 자실 입원치료 18 명과 입원 치료 후 한 달 이내 재입원한 환자는 47명이었다(Table 1).

\section{2. 각 바이러스의 임상적 특징}

한 가지 바이러스만 검출된 1,168 명을 대상으로 각 바이러 스에 따른 임상적 특징을 살펴보면, RSV에서 입원 시 나이가 0.4 세로 제일 어렸고 $\mathrm{HBoV}$ 에서 입원기간이 6.5 일로 가장 길었으며, 산소치료비율(6/24명, 25.0\%)이 가장 높았다. 하 지만, $\mathrm{HBoV}$ 와 $\mathrm{HCoV}$ 의 경우 2013년도 7월부터 검사가 시행 되었고 검출된 환자 수도 적었기 때문에 임상적인 차이에 의미를 두기 어려웠다. 이 두 가지 바이러스를 제외했을 경우, $\mathrm{RSV}$ 에서 산소치료(73/470명, 15.5\%)와 중환자실치료(13/
470 명, $2.8 \%$ )가 가장 많이 필요로 하였다. 그리고 하기도 감염 으로 입원 치료 후 한 달 이내 다시 하기도 감염으로 재입원 한 경우는 HRV에서 제일 많았다(21/219명, 9.6\%) (Table 2).

\section{3. 호흡기 바이러스의 분포 양상}

\section{1) 나이별 분포}

1-5세에서 569명(48.7\%)으로 가장 많았으며, 1 세 미만 559명(47.9\%), 6-9세 30명(2.6\%), 10세 이상 10명(0.9\%)이 었다. 또한 가장 흔한 바이러스가 나이에 따라 다른 분포를 보였는데( $p<0.001), \mathrm{RSV}$ 는 1 세 미만에서 326명(58.3\%)으 로 가장 많았고, 나이가 많아질수록 감소하는 경향을 보였고 $(p<0.001), \mathrm{PIV}$ 는 1-5세에서 149명(26.2\%)으로 가장 많았 고 6세 이후로 감소하는 경향을 보였다( $p=0.015)$. Influ A와 Influ B 모두 나이가 많아질수록 증가하는 경향을 보였고

Table 1. Characteristics of the study population

\begin{tabular}{lc}
\hline \multicolumn{1}{c}{ Characteristic } & Total $(\mathrm{n}=1,168)$ \\
\hline Age $(\mathrm{y})$ & $1.0[0.2-2.1]$ \\
Sex (male/female) & $717 / 451(61.4 / 38.6)$ \\
Hospital (PNUCH/PNUH) & $901 / 267(77.1 / 22.9)$ \\
Year & \\
2012 & $476(40.8)$ \\
2013 & $339(29.0)$ \\
2014 & $353(30.2)$ \\
Season & \\
Spring & $337(28.9)$ \\
Summer & $151(12.9)$ \\
Fall & $343(29.4)$ \\
Winter & $337(28.9)$ \\
Diagnosis & \\
Croup & $204(17.5)$ \\
Tracheobronchitis & $88(7.5)$ \\
Bronchiolitis & $372(31.8)$ \\
Pneumonia & $493(42.2)$ \\
Asthma & $40(3.4)$ \\
Past history of asthma & $95(8.1)$ \\
Length of hospitalization (d) & $6.0[4.0-7.0]$ \\
Oxygen supplementation & $123(10.5)$ \\
Care in the ICU & $18(1.5)$ \\
Readmission within a month & $47(4.0)$ \\
\hline
\end{tabular}

Values are presented as median [interquartile range] or number (\%).

PNUCH, Pusan National University Children's Hospital; PNUH, Pusan National University Hospital; ICU, intensive care unit. 
$(p<0.001), \mathrm{HRV}$ 는 6세 이상에서 가장 흔한 원인이었고, 나 이가 많아질수록 증가하는 경향을 보였다 $(p<0.001)$ (Fig. 1).

\section{2) 진단별 분포}

폐렴이 469명(40.1\%)으로 가장 많았고, 세기관지염 368 명(31.5\%), 크룹 204명(17.4\%), 기관기관지염 87명(7.4\%), 천식 40명(3.4\%) 순이었다. 폐렴과 세기관지염의 가장 흔한 원인은 RSV로 각각 195명(41.6\%)과 233명(63.3\%)이었고, 두 번째로 흔한 원인은 $\mathrm{HRV}$ 로 각각 88명(18.8\%)과 59명 (16.0\%)이었다. 크룹의 가장 흔한 원인은 PIV로 107명(52.5\%) 이었고, Influ A가 다음으로 흔한 원인이었다. 천식 악화로 입원한 소아에서는 HRV가 28명(70.0\%)으로 가장 큰 비율 을 차지하였다(Fig. 2).

\section{4. 나이에 따른 진단}

폐렴과 크룹 모두 영아에서 1-5세에 이르기까지 증가하다 가 6세 이후로 감소하였고( $p<0.001)$, 세기관지염은 영아시
기에 315 명(56.4\%)으로 제일 많았고, 1 세 이후로 감소하였다 $(p<0.001)$. 천식은 1-5세에서 24명(4.0\%)으로 제일 많았으나 비율은 높지 않았고, 나이가 많아질수록 원인질환으로 차지 하는 비율이 증가하였으며 $(p<0.001)$, 기관기관지염은 $1-5$ 세 에서 49명(8.6\%)으로 제일 많았으나 나이에 따른 경향성은 없었다 $(p=0.117$ ) (Fig. 3).

\section{5. 한 달 이내 재입원에 영향을 미치는 요인}

한 가지 바이러스만 검출된 1,168 명 가운데 한 달 이내 재입원한 환자는 47 명이었다. 단변량 로지스틱회귀분석을 통해 입원 기간, 특정 병원(Pusan National University Hospital, $\mathrm{PNUH}$ ), 천식 과거력, RSV과 HRV가 의미 있는 요인으 로 확인되었다. 나이, 성별 및 입원 병원을 보정한 다변량 로지스틱회귀분석을 통해 확인된 재입원의 위험요인은 천식 과거력 $(\mathrm{aOR}[95 \% \mathrm{CI}]=2.38$ [0.97-5.31], $p=0.044)$ 과 $\mathrm{HRV}$ $(\mathrm{aOR}[95 \% \mathrm{CI}]=3.42$ [1.81-6.40), $p<0.001)$ 였고, $\mathrm{RSV}$ 는 재 입원의 위험이 감소하였다 $(\mathrm{aOR}[95 \% \mathrm{CI}]=0.39$ [0.18-0.80],

Table 2. Comparisons of clinical characteristics according to respiratory viruses $(n=1,168)$

\begin{tabular}{|c|c|c|c|c|c|c|c|c|c|}
\hline Characteristic & $\begin{array}{l}\text { HAdV } \\
(n=24)\end{array}$ & $\begin{array}{l}\text { HBoV } \\
(n=24)\end{array}$ & $\begin{array}{l}\mathrm{HCoV} \\
(n=15)\end{array}$ & $\begin{array}{c}\text { hMPV } \\
(\mathrm{n}=103)\end{array}$ & $\begin{array}{c}\text { HRV } \\
(n=219)\end{array}$ & $\begin{array}{l}\text { Influ.A } \\
(n=57)\end{array}$ & $\begin{array}{l}\text { Influ.B } \\
(n=23)\end{array}$ & $\begin{array}{c}\text { PIV } \\
(n=233)\end{array}$ & $\begin{array}{c}\text { RSV } \\
(n=470)\end{array}$ \\
\hline Age (y) & $1.8[1.0-3.0]$ & $1.0[0.8-1.7]$ & $1.2[0.3-1.7]$ & $1.3[0.6-2.3]$ & $1.8[0.6-3.0]$ & $2.0[1.2-3.0]$ & $2.1[1.1-4.5]$ & $1.2[0.8-2.0]$ & $0.4[0.2-1.2]$ \\
\hline Sex (male) & $16(66.7)$ & $16(66.7)$ & $9(60.0)$ & $68(66.0)$ & $151(68.9)$ & $32(56.1)$ & $12(52.2)$ & $130(55.8)$ & $283(60.2)$ \\
\hline \multicolumn{10}{|l|}{ Season } \\
\hline Spring & $9(37.5)$ & $15(62.5)$ & $1(6.7)$ & 83 (80.6) & 75 (34.2) & $10(17.5)$ & $13(56.5)$ & 97 (41.6) & $34(7.2)$ \\
\hline Summer & $4(16.7)$ & $6(25.0)$ & $1(6.7)$ & $4(3.9)$ & $37(16.9)$ & $0(0.0)$ & $0(0.0)$ & $82(35.2)$ & $17(3.6)$ \\
\hline Fall & $4(16.7)$ & $2(8.3)$ & $6(40.0)$ & $3(2.9)$ & 79 (36.1) & $0(0.0)$ & $0(0.0)$ & 34 (14.6) & $215(45.7)$ \\
\hline Winter & $7(29.2)$ & $1(4.2)$ & $7(46.7)$ & 13 (12.6) & $28(12.8)$ & $47(82.5)$ & $10(43.5)$ & $20(8.6)$ & $204(43.4)$ \\
\hline \multicolumn{10}{|l|}{ Diagnosis } \\
\hline Croup & $4(16.7)$ & $1(4.2)$ & $6(40.0)$ & 14 (13.6) & $17(7.8)$ & $29(50.9)$ & $8(34.8)$ & $107(45.9)$ & $18(3.8)$ \\
\hline Tracheobronchitis & $3(12.5)$ & $2(8.3)$ & $4(26.7)$ & $3(2.9)$ & $27(12.3)$ & $4(7.0)$ & $2(8.7)$ & $22(9.4)$ & $20(4.3)$ \\
\hline Bronchiolitis & $3(12.5)$ & $9(37.5)$ & $3(20.0)$ & $30(29.1)$ & $59(26.9)$ & $3(5.3)$ & $2(8.7)$ & $26(11.2)$ & $233(49.6)$ \\
\hline Pneumonia & $14(58.3)$ & $12(50.0)$ & $2(13.3)$ & $52(50.5)$ & $88(40.2)$ & $19(33.3)$ & $10(43.5)$ & $77(33.0)$ & 195 (41.5) \\
\hline Asthma & $0(0.0)$ & $0(0.0)$ & $0(0.0)$ & $4(3.9)$ & $28(12.8)$ & $2(3.5)$ & $1(4.3)$ & $1(0.4)$ & $4(0.9)$ \\
\hline Past history of asthma & $3(12.5)$ & $3(12.5)$ & $1(6.7)$ & $5(4.9)$ & $52(23.7)$ & $4(7.0)$ & $1(4.3)$ & $7(3.0)$ & $19(4.0)$ \\
\hline Asthma attack & $2(8.3)$ & $3(12.5)$ & $1(6.7)$ & $6(5.8)$ & $65(29.7)$ & $4(7.0)$ & $3(13.0)$ & $8(3.4)$ & $18(3.8)$ \\
\hline Length of hospitalization (d) & $5.5[4.0-8.0]$ & $6.5[5.0-9.0]$ & $4.0[3.5-5.5]$ & $6.0[5.0-8.0]$ & $6.0[4.0-8.0]$ & $5.0[4.0-7.0]$ & $5.0[4.0-6.0]$ & $5.0[4.0-6.0]$ & $6.0[5.0-8.0]$ \\
\hline Oxygen supplementation & $1(4.2)$ & $6(25.0)$ & $1(6.7)$ & $6(5.8)$ & $28(12.8)$ & $1(1.8)$ & $0(0.0)$ & $7(3.0)$ & $73(15.5)$ \\
\hline Care in the ICU & $0(0.0)$ & $0(0.0)$ & $1(6.7)$ & $2(1.9)$ & $1(0.5)$ & $0(0.0)$ & $0(0.0)$ & $1(0.4)$ & $13(2.8)$ \\
\hline Readmission within a month & $2(8.3)$ & $0(0.0)$ & $1(6.7)$ & $5(4.9)$ & $21(9.6)$ & $2(3.5)$ & $0(0.0)$ & $7(3.0)$ & $9(1.9)$ \\
\hline
\end{tabular}

Values are presented as median [interquartile range] or number (\%).

ICU, intensive care unit; HAdV, human adenovirus; HBoV, human bocavirus; HCoV, human coronavirus; hMPV, human metapneumovirus; HRV, human rhinovirus; Influ A, influenza virus type A; Influ B, influenza virus type B; PIV, parainfluenza virus; RSV, respiratory syncytial virus. 
$p=0.01)$ (Table 3).

\section{고 찰}

급성 하기도 감염은 고소득국가와 저소득국가를 불문하고 유병률이 높기 때문에 경제적 부담이 상당하며, 특히 입원이 필요한 환자와 그들의 가족, 그리고 의료시스템적인 부분에 있어서 직간접적으로 많은 사회경제적 비용이 든다[14]. 소아 에서는 바이러스에 의한 급성 하기도 감염이 가장 흔하며, 경미한 질환에서부터 중증 질환까지 다양한 임상 양상을 보 일 수 있는데, 특히 5 세 미만 소아에서 높은 이환율과 사망률 을 보인다[15]. 이번 연구에서도 1 세 미만이 672명, 1-5세가 685 명으로 5 세 이하 연령이 $96.9 \%$ 를 차지하였다.

최근 메타분석 연구에서 환자대조군 연구를 종합한 결과 에 따르면 5 세 미만 소아에서 급성 하기도 감염과 관련하여 가장 큰 인과관계를 보였던 바이러스는 RSV였고, 다음으로 influenza virus, PIV, hMPV 순이었으며 HRV는 약한 인과관 계를 보인 반면, $\mathrm{HAdV}, \mathrm{HBoV}$ 와 $\mathrm{HCoV}$ 는 인과관계를 보이 지 않았다[16]. 국내 보고에 따르면 대개 5 세 미만 소아에서 급성 하기도 감염의 가장 흔한 원인은 RSV였다[2,17]. RSV 는 영유아에서 폐렴과 세기관지염의 중요한 원인으로 알려 져 있다[18,19]. 2000년부터 2004년까지 5년간 시행된 전향 적 연구에서 급성 호흡기 감염으로 내원한 5 세 미만 소아 가운데 입원 환자의 $20 \%$, 응급실 환자의 $18 \%$, 외래 환자의 $15 \%$ 에서 RSV가 원인이었다[20]. 한 메타분석연구에 따르면 2005년 한 해 동안 5 세 미만 소아에서 전세계적으로 RSV와 관련하여 새롭게 발생한 하기도 감염이 3,380만 사례였다 [21]. 또한, 입원을 필요로 하는 심한 감염은 340 만 사례였으 며, 특히 사망한 사례가 66,000-199,000명으로 추산되었고 그 중 $99 \%$ 가 개발도상국에서 발생하였다[21]. 본 연구에서 도 RSV가 470/1,168명(40.2\%)으로 가장 흔한 원인이었고, 대부분(468/470명, 99.6\%)의 환자가 5세 이하였으며, 폐렴
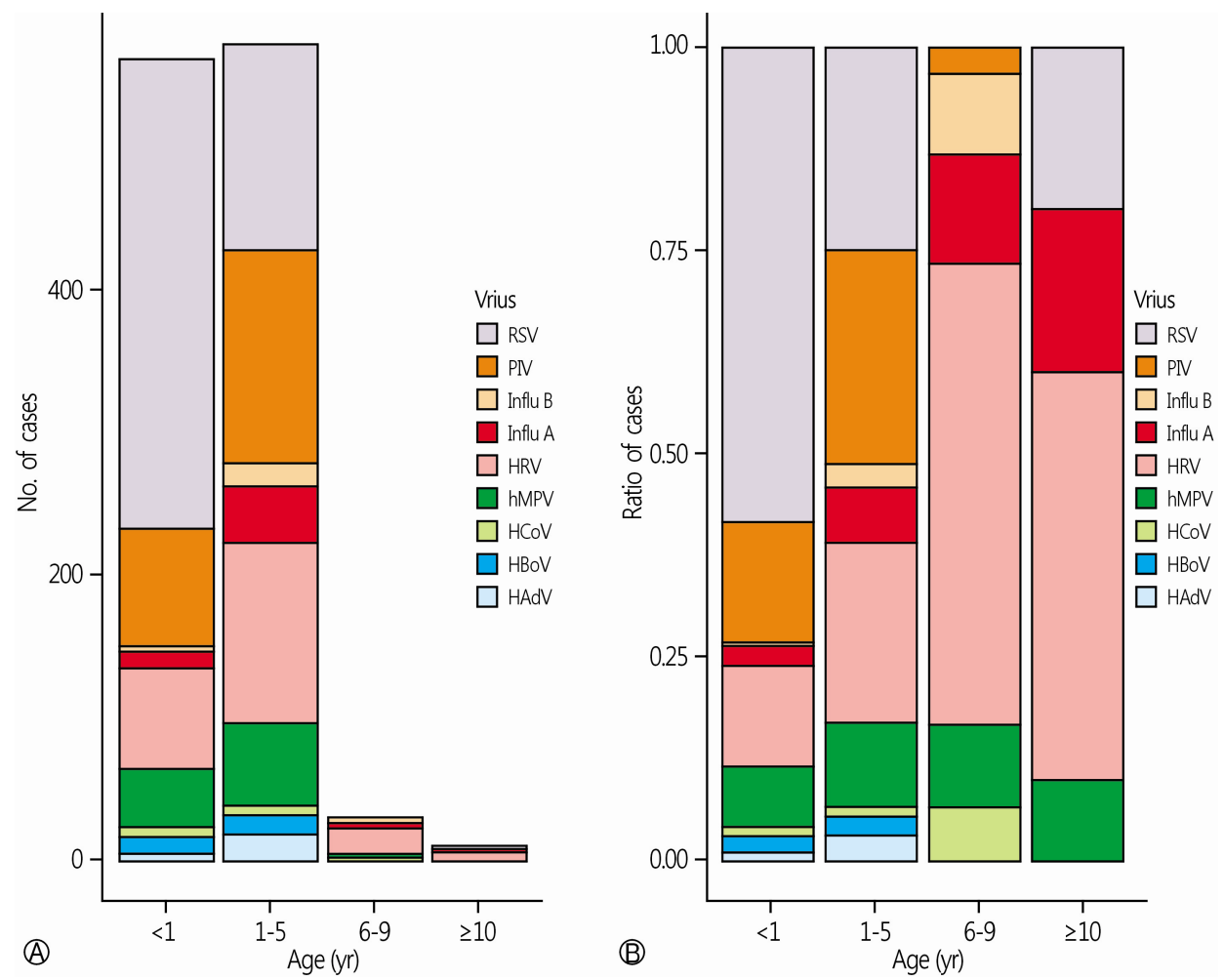

Fig. 1. Distribution of viruses according to age. The overall distribution of viruses according to age is significantly different $(p<0.001$, analyzed by using the Mantel-Haenszel chi-square test for trend). In patient under 5 year-old, the most common viruses according to age are different; RSV under 1 year old, PIV ( $p=0.015$ ) from 1 to 5 years old, and HRV over 6 years old. HAdV, human adenovirus; $\mathrm{HBoV}$, human bocavirus; $\mathrm{HCoV}$, human coronavirus; hMPV, human metapneumovirus; $\mathrm{HRV}$, human rhinovirus; Influ A, influenza virus type A; Influ B, influenza virus type B; PIV, parainfluenza virus; RSV, respiratory syncytial virus. 
195/469명(41.6\%)과 세기관지염 233/368명(63.3\%)이었다. 또한 2013년 도중에 시행되었고 검출된 환자 수가 적었던 $\mathrm{HCoV}$ 와 $\mathrm{HBoV}$ 를 제외했을 경우 RSV에서 산소투여와 중환 자실치료를 받았던 환자가 가장 많아서 중증도가 높았다.

$\mathrm{RSV}$ 와 비슷한 임상 양상을 보이는 $\mathrm{hMPV}$ 는 2001년에 처음 보고된 이후로 영유아에서 급성 호흡기 감염을 일으키는 중 요한 바이러스로 알려졌다[22,23]. 2003년부터 2009년까지 7년간의 전향적 연구에서 급성 호흡기 질환으로 내원한 5 세 미만 소아 가운데 입원 환자 200/3,490명(6\%), 외래 환자 222/3,257명(7\%), 응급실 환자 224/3001명(7\%)에서 hMPV 가 원인이었다[24]. RSV와 hMPV를 비교한 국내연구에서 두 가지 바이러스 모두 폐렴과 세기관지염의 주된 원인이었 으나, $\mathrm{hMPV}$ 군에서 환자 나이가 많았고 발열 빈도가 더 높았 으며, 상대적으로 세기관지염이 더 적었고 폐렴은 더 많이 발생하였다[25]. 영아를 대상으로 바이러스에 따른 세기관 지염의 임상경과를 비교한 전향적 연구에서 각 바이러스에 따라 입원 시 산소포화도, 임상점수, 산소투여기간과 입원기 간을 비교하였는데, RSV군이 $\mathrm{hMPV}$ 군에 비해 입원 시 산소
포화도가 낮고, 임상점수가 높으며, 입원 기간이 길어 더 높은 중증도를 보였다[26]. 본 연구 결과에서 $\mathrm{hMPV}$ 는 대부분이 5 세 이하 소아(99/103명, 96.1\%)에서 검출되었으나 나이에 따른 비율은 7.3-10.2\%로 대체로 비슷하였다. 발병 양상은 폐렴과 모세기관지염이 82/103명(76.6\%)을 차지하였고, RSV 에 비하여 폐렴 비율이 높고(50.5\% vs. $41.5 \%)$ 세기관지염 비율은 낮아서(29.1\% vs. $49.6 \%)$ 이전 국내 연구결과와 비슷 하였다. 임상경과에 있어 입원기간은 6 일로 비슷했던 반면 에, 산소투여 $(5.8 \%)$ 와 중환자실 치료(1.9\%)를 받았던 환자 는 적어서 중증도가 더 낮았다.

급성 하기도 감염이 심할 경우 입원기간이 길어지거나 중 환자실에서 치료하게 되는데, 이처럼 중증도가 심한 호흡기 감염은 대개 미숙아나 기관지폐이형성증과 만성질환을 가진 소아에서 주로 문제가 되며[27-29], 특히 미숙아의 경우 RSV 와 같은 특정 바이러스에 의한 심한 감염이 흔하다고 알려져 있다[30,31]. 본 연구에서 중환자실 치료에 있어서 각 바이러 스에 따른 차이는 없었다(data not shown). 다만, 호흡기 바이 러스 중복 감염자를 제외하였기에 중복 감염이 중증도에 미
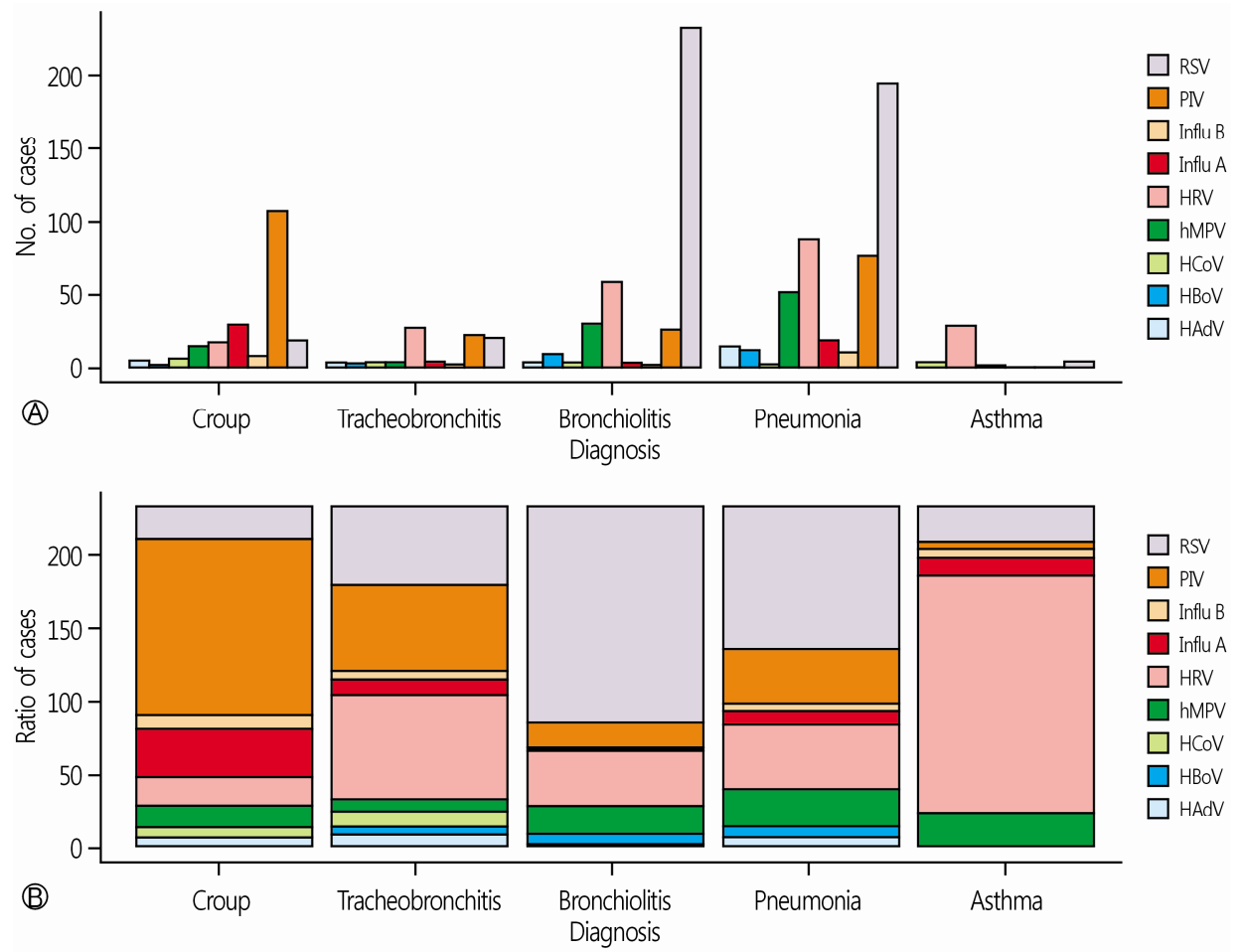

Fig. 2. Distribution of viruses according to clinical diagnosis. RSV is the most commonly detected agent of bronchiolitis and pneumonia and HRV is the second most common cause of these diseases. Croup is mostly caused by parainfluenza virus, whereas asthma is predominantly caused by HRV. $\mathrm{HAdV}$, human adenovirus; $\mathrm{HBoV}$, human bocavirus; $\mathrm{HCoV}$, human coronavirus; hMPV, human metapneumovirus; HRV, human rhinovirus; Influ A, influenza virus type A; Influ B, influenza virus type B; PIV, parainfluenza virus; RSV, respiratory syncytial virus. 
치는 영향을 확인하기 어려우나, 한 연구에 따르면 기저질환 이 없는 환자에서는 검출된 호흡기 바이러스의 수가 많더라 도 질병의 중증도와는 관련이 없었다[32].

급성 호흡기 감염에 대한 사회경제적 부담과 관련한 여러 지표 중 하나로 한 달 이내 재입원에 미치는 요인에 대해 알아보았다. 이번 연구에서 $\mathrm{PNUH}$ 의 OR이 6.62로 가장 높
았는데, 이는 입원 기준, 환자의 구성, 병원 인근 지역사회의 특성 등의 차이에 의한 것으로 생각되며, 그 외에는 천식 병력과 $\mathrm{HRV}$ 감염이 재입원의 위험인자로 확인되었다. $\mathrm{HRV}$ 는 영유아기 천명의 흔한 유발인자이며[33], 특히 3세 이전 에 $\mathrm{HRV}$ 로 인한 천명은 향후 천식으로 이행하는데 있어 중요 한 위험요인으로 알려져 있다[34]. 또한 $\mathrm{HRV}$ 와 관련된 천명
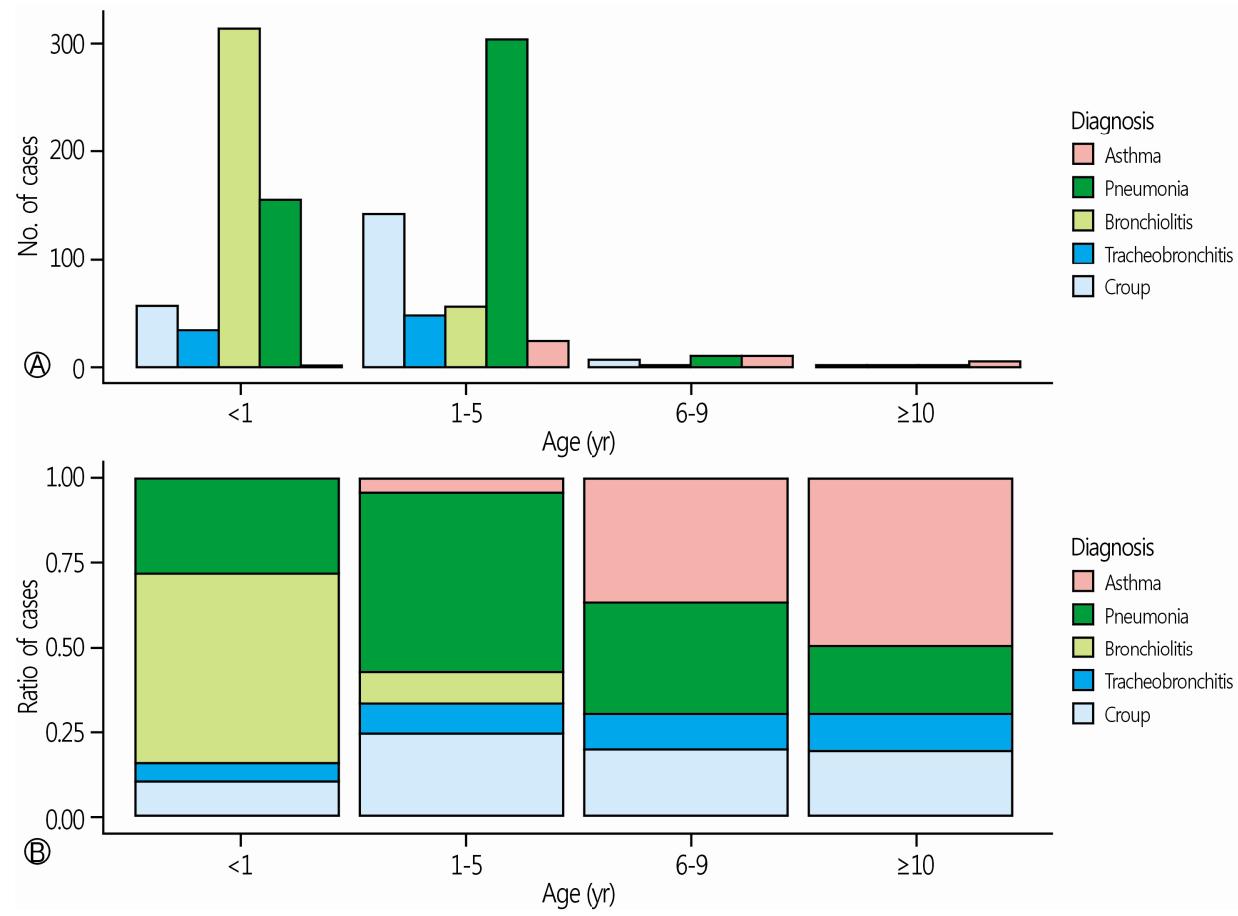

Fig. 3. Distribution of clinical diagnoses according to age. The overall distribution of diagnoses according to age is significantly different $(p<0.001$, analyzed by using the Mantel-Haenszel chisquare test for trend). Bronchiolitis is most common respiratory tract infection under 1 year old, whereas pneumonia is most common in children aged 1 to 5 years.

Table 3. Odds ratio for effects of predictor variables on readmission within a month $(n=47)$

\begin{tabular}{lcrrr}
\hline & \multicolumn{2}{c}{ Univariate } & \multicolumn{2}{c}{ Multivariate } \\
\cline { 2 - 5 } & OR $(95 \%$ CI) & $p$-value & OR $^{\text {a) }}(95 \%$ CI $)$ & $p$-value \\
\hline Age (y) & $1.03(0.87-1.17)$ & 0.731 & $1.00(0.84-1.14)$ & 0.972 \\
Sex (male) & $1.11(0.61-2.09)$ & 0.726 & $1.18(0.64-2.24)$ & 0.598 \\
Hospital (PNUH) & $6.58(3.61-12.38)$ & $<0.001$ & $6.62(3.63-12.47)$ & $<0.001$ \\
Length of hospitalization (d) & $1.12(1.03-1.21)$ & 0.004 & $1.08(0.99-1.17)$ & 0.085 \\
Oxygen supplementation & $1.01(0.34-2.38)$ & 0.981 & $1.20(0.40-2.92)$ & 0.717 \\
Care in the ICU & $1.41(0.08-7.11)$ & 0.740 & $1.03(0.06-5.74)$ & 0.974 \\
Past history of asthma & $2.85(1.26-5.84)$ & 0.007 & $2.38(0.97-5.31)$ & 0.044 \\
RSV & $0.34(0.15-0.68)$ & 0.004 & $0.35(0.15-0.72)$ & 0.007 \\
HRV & $3.77(2.06-6.82)$ & $<0.001$ & $3.42(1.81-6.40)$ & $<0.001$ \\
\hline All
\end{tabular}

All data were analyzed with logistic regression method.

OR, odds ratio; CI, confidence interval; PNUH, Pusan National University Hospital; ICU, intensive care unit; RSV, respiratory syncytial virus; HRV, human rhinovirus.

a) The odds ratio was adjusted for age, sex, and hospital. 
이 있었던 소아에서 다른 바이러스에 감염된 환자보다 급성 호흡기 질환 이후 재입원의 위험이 높았고, 특히 $\mathrm{HRV} \mathrm{C}$ 형에 서 연관성이 두드러졌다[35]. 이번 연구에서도 $\mathrm{HRV}$ 감염과 천식 병력 간에 유의한 상관성을 보였다(data not shown). 반면, RSV 감염은 재입원의 위험을 $65 \%$ 감소시키는 것으로 확인되었는데, 이는 주로 RSV 감염으로 인한 입원의 위험을 높일 수 있는 미숙아, 기관지폐이형성증과 선천성심장질환 등 기저질환을 가진 소아를 제외한 것이 영향을 미친 것으로 여겨진다.

이번 연구는 부산과 양산 두 도시의 대학병원에서 시행된 연구로 전국적인 역학을 대변하기 어렵고 상대적으로 중증 의 환자가 입원할 수 있어 선택편견이 있을 수 있다. 또한 호흡기 바이러스의 영향만을 보기 위해 세균성 감염을 배제 하고자 하였으나 2 차 세균감염 등과 같은 세균의 영향을 현 실적으로 모두 배제하기 어려운 점이 있다. 한 달 이내 재입 원한 환자가 47 명으로 적었기 때문에 재입원의 위험요인을 더 정확하게 규명하기 위해서는 장기간에 걸쳐 더 많은 환자 를 대상으로 한 전향적인 연구가 필요하다.

이번 연구를 통해 기저질환이 없는 건강한 소아에서 발생 한 급성 하기도 감염의 원인 호흡기 바이러스에 따른 임상적, 역학적 특성과 더불어 급성 하기도 감염 이후 한 달 이내 재입원을 일으키는 위험요인에 대해서 확인할 수 있었다.

\section{ACKNOWLEDGEMENT}

이 논문은 부산대학교 기본연구지원사업(2년)에 의하여 연구되었습니다.

\section{CONFLICT OF INTEREST}

No potential conflict of interest relevant to this article was reported.

\section{ORCID}

Hyung Young Kim, http://orcid.org/0000-0001-8591-1783

Hee-Ju Park, http://orcid.org/0000-0002-2782-3918

\section{REFERENCES}

1. Kwak KJ, Kim YH, Choi HJ. Clinical characteristics of respi- ratory viral infection in children during spring/summer: focus on human bocavirus. Allergy Asthma Respir Dis 2015;3:4106. Korean

2. Lim JS, Woo SI, Kwon HI, Baek YH, Choi YK, Hahn YS. Clinical characteristics of acute lower respiratory tract infections due to 13 respiratory viruses detected by multiplex PCR in children. Korean J Pediatr 2010;53:373-9. Korean.

3. Choi EH, Lee HJ, Kim SJ, Eun BW, Kim NH, Lee JA, et al. The association of newly identified respiratory viruses with lower respiratory tract infections in Korean children, 20002005. Clin Infect Dis 2006;43:585-92.

4. Selwyn BJ. The epidemiology of acute respiratory tract infection in young children: comparison of findings from several developing countries. Coordinated Data Group of BOSTID Researchers. Rev Infect Dis 1990;12(Suppl 8):S870-88.

5. Shann F. Etiology of severe pneumonia in children in developing countries. Pediatr Infect Dis 1986;5:247-52.

6. Cheong HY, Lee JH, Kim YB, Nam HS, Choi YJ, Kim CJ, et al. Viral etiologic agents in acute viral lower respiratory tract detected by multiplex RT-PCR. Pediatr Allergy Respir Dis 2007; 17:334-53. Korean.

7. Kwon JH, Chung YH, Lee NY, Chung EH, Ahn KM, Lee SI. An epidemiological study of acute viral lower respiratory tract infections in hospitalized children from 2002 to 2006 in Seoul, Korea. Pediatr Allergy Respir Dis 2008;18:26-36. Korean.

8. Kim SH, Huh JH, Bae SY, Kim JS, Yoon SY, Lim CS, et al. Epidemiology of respiratory viral infection in 2004-2006. Korean J Lab Med 2006;26:351-7. Korean.

9. Kim KH, Kim JH, Kim KH, Kang C, Kim KS, Chung HM, et al. Identification of viral pathogens for lower respiratory tract infection in children at seoul during autumn and winter seasons of the year of 2008-2009. Korean J Pediatr Infect Dis 2010;17:49-55. Korean.

10. Kim HY, Kim KM, Kim SH, Son SK, Park HJ. Clinical manifestations of respiratory viruses in hospitalized children with acute viral lower respiratory tract infections from 2010 to 2011 in Busan and Gyeongsangnam-do, Korea. Pediatr Allergy Respir Dis 2012;22:265-72. Korean.

11. Denny FW, Clyde WA Jr. Acute lower respiratory tract infections in nonhospitalized children. J Pediatr 1986;108:635-46.

12. Chai H, Farr RS, Froehlich LA, Mathison DA, McLean JA, Rosenthal RR, et al. Standardization of bronchial inhalation challenge procedures. J Allergy Clin Immunol 1975;56:323-7.

13. Castro-Rodríguez JA, Holberg CJ, Wright AL, Martinez FD. A clinical index to define risk of asthma in young children with recurrent wheezing. Am J Respir Crit Care Med 2000; 162:1403-6.

14. Paramore LC, Ciuryla V, Ciesla G, Liu L. Economic impact of respiratory syncytial virus-related illness in the US: an analysis of national databases. Pharmacoeconomics 2004;22: 275-84.

15. Pedraza-Bernal AM, Rodriguez-Martinez CE, Acuña-Cordero R. Predictors of severe disease in a hospitalized population of children with acute viral lower respiratory tract infections. J Med Virol 2016;88:754-9. 
16. Shi T, McLean K, Campbell H, Nair H. Aetiological role of common respiratory viruses in acute lower respiratory infections in children under five years: a systematic review and meta-analysis. J Glob Health 2015;5:010408.

17. Kwon JM, Shim JW, Kim DS, Jung HL, Park MS, Shim JY. Prevalence of respiratory viral infection in children hospitalized for acute lower respiratory tract diseases, and association of rhinovirus and influenza virus with asthma exacerbations. Korean J Pediatr 2014;57:29-34.

18. Hall CB. Respiratory syncytial virus and parainfluenza virus. N Engl J Med 2001;344:1917-28.

19. Weber MW, Mulholland EK, Greenwood BM. Respiratory syncytial virus infection in tropical and developing countries. Trop Med Int Health 1998;3:268-80.

20. Hall CB, Weinberg GA, Iwane MK, Blumkin AK, Edwards $\mathrm{KM}$, Staat MA, et al. The burden of respiratory syncytial virus infection in young children. N Engl J Med 2009;360:588-98.

21. Nair H, Nokes DJ, Gessner BD, Dherani M, Madhi SA, Singleton RJ, et al. Global burden of acute lower respiratory infections due to respiratory syncytial virus in young children: a systematic review and meta-analysis. Lancet 2010;375:154555.

22. Esper F, Martinello RA, Boucher D, Weibel C, Ferguson D, Landry ML, et al. A 1-year experience with human metapneumovirus in children aged $<5$ years. J Infect Dis 2004;189: 1388-96.

23. Williams JV, Harris PA, Tollefson SJ, Halburnt-Rush LL, Pingsterhaus JM, Edwards KM, et al. Human metapneumovirus and lower respiratory tract disease in otherwise healthy infants and children. N Engl J Med 2004;350:443-50.

24. Edwards KM, Zhu Y, Griffin MR, Weinberg GA, Hall CB, Szilagyi PG, et al. Burden of human metapneumovirus infection in young children. N Engl J Med 2013;368:633-43.

25. Chung WJ, Kang SS, Bang KW, Chun YH, Yoon JS, Kim $\mathrm{HH}$, et al. Comparison of respiratory disease by human metapneumovirus and respiratory syncytial virus in children. Allergy Asthma Respir Dis 2013;1:157-63. Korean.
26. Marguet C, Lubrano M, Gueudin M, Le Roux P, Deschildre A, Forget $C$, et al. In very young infants severity of acute bronchiolitis depends on carried viruses. PLoS One 2009;4: e4596.

27. Meissner HC. Economic impact of viral respiratory disease in children. J Pediatr 1994;124:S17-21.

28. Purcell K, Fergie J. Driscoll Children's Hospital respiratory syncytial virus database: risk factors, treatment and hospital course in 3308 infants and young children, 1991 to 2002. Pediatr Infect Dis J 2004;23:418-23.

29. Hon KL, Leung TF, Cheng WY, Ko NM, Tang WK, Wong WW, et al. Respiratory syncytial virus morbidity, premorbid factors, seasonality, and implications for prophylaxis. J Crit Care 2012;27:464-8.

30. Kimpen JL, Simoes EA. Respiratory syncytial virus and reactive airway disease. New developments prompt a new review. Am J Respir Crit Care Med 2001;163:S1.

31. Ogra PL. Respiratory syncytial virus: the virus, the disease and the immune response. Paediatr Respir Rev 2004;5(Suppl A): S119-26.

32. Morikawa S, Kohdera U, Hosaka T, Ishii K, Akagawa S, Hiroi $\mathrm{S}$, et al. Seasonal variations of respiratory viruses and etiology of human rhinovirus infection in children. J Clin Virol 2015; 73:14-9.

33. Lemanske RF Jr, Jackson DJ, Gangnon RE, Evans MD, Li Z, Shult PA, et al. Rhinovirus illnesses during infancy predict subsequent childhood wheezing. J Allergy Clin Immunol 2005; 116:571-7.

34. Jackson DJ, Gangnon RE, Evans MD, Roberg KA, Anderson EL, Pappas TE, et al. Wheezing rhinovirus illnesses in early life predict asthma development in high-risk children. Am J Respir Crit Care Med 2008;178:667-72.

35. Cox DW, Bizzintino J, Ferrari G, Khoo SK, Zhang G, Whelan $\mathrm{S}$, et al. Human rhinovirus species $\mathrm{C}$ infection in young children with acute wheeze is associated with increased acute respiratory hospital admissions. Am J Respir Crit Care Med 2013;188:1358-64. 